\title{
Wyłom w antropocentryzmie i gatunkowizmie? Przemiany świadomości kulturowej na przykładzie relacji: człowiek - zwierzęce gatunki nie-ludzkie w drugiej połowie XIX wieku
}

Druga połowa XIX stulecia przyniosła rewolucyjną zmianę w paradygmacie nauk biologicznych. Wywołała ona ogromny wstrząs światopoglądowy, wpłynęła na wszystkie rodzaje dyskursów intelektualnych epoki, wreszcie zainicjowała kres filozofii antropocentrycznych ${ }^{1}$. Teoria ewolucji Darwina - bo to głównie ona na tę zmianę się złożyła - scaliła ideę rozwoju naturalnego w sposób dogłębnie przemyślany i koncepcyjnie spójny, przy czym jej zasadą naczelną okazał się mechanizm doboru naturalnego. Jedną z najistotniejszych konsekwencji tej rewolucyjnej teorii stała się krytyczna rewizja tradycyjnej metafizyki i antropologii filozoficznej, polegająca na osłabieniu uprzywilejowanej pozycji gatunku homo sapiens $\mathrm{w}$ makrokosmosie natury ${ }^{2}$. Gatunek ludzki został ściśle połączony $\mathrm{z}$ materialnym środowiskiem, funkcjonował $\mathrm{w}$ relacjach $\mathrm{z}$ innymi gatunkami, stracił supranaturalną genezę.

W naukowym i popularnonaukowym piśmiennictwie pozytywistycznym drugiej połowy XIX wieku - stanowiącym główny przedmiot niniejszego

1 Pogląd taki - powszechnie już dziś akceptowany - głoszą też wybitni biolodzy, np. Ernest Mayr (Mayr 2011: 30).

2 Już współcześni Darwina podkreślali rewolucyjny charakter jego dzieła. Emil Du Bois-Reymond - w odczycie wygłoszonym w 1883 roku - nazwał autora O pochodzeniu gatunków „Kopernikiem świata organicznego” (Du Bois-Reymond 2011: 244). 
studium - można odnaleźć wiele śladów tej przemiany³ nie nastąpiła ona nagle ani całkowicie, miała charakter procesualny, była pełna niekonsekwencji, wzbudzała kontrowersje i polemiki. Uczeni i filozofowie odwołujący się do hipotez Darwina oraz związanej z nimi koncepcji metafizycznej i antropologicznej zasadniczo przynależni do pozytywistycznej formacji umysłowej - nie mogli sobie, rzecz jasna, uświadamiać tych problemów, które pojawiły się w wyniku fundamentalnych przewartościowań poznania naukowego, wywołanych dopiero przez namysł nad antropocenem, posthumanizmem, eko- i zookrytyką. Wprawdzie przełamali oni metafizyczną opozycję natury i kultury, ale nie potrafili w sposób kompleksowy dostrzec ani destrukcyjnej roli człowieka w ekosystemie, ani też korelacji między wszystkimi formami materii ożywionej i nieożywionej, nie opowiadali się jeszcze za egalitaryzmem gatunkowym. Ich świadomość poznawczą kształtowała matryca deterministycznego progresywizmu, przybierająca postać teleologiczną. Natura, za której część uznawali gatunek ludzki, była dla nich - w sensie epistemologicznym i metodologicznym - obiektem poddawanym poznawczej eksploracji i technologicznej eksploatacji.

Przełamywanie paradygmatu antropocentrycznego następowało powoli. Godne odnotowania, że wyraźne ślady tego procesu można odnaleźć już w poglądach i pismach romantyków. Choć nie odwoływali się oni do argumentacji naukowej, to byli wyczuleni na wspólnotę wszystkich istnień, tak organicznych, jak i nieorganicznych. Piękną kartę zapisał Adam Mickiewicz, który w Wykładzie X czwartego kursu Literatury słowiańskiej podkreślał nieuprawnione i bezwzględne panowanie człowieka nad naturą i zwierzętami (Mytych-Forajter 2017: 20). Duchowe pokrewieństwo człowieka ze zwierzęciem i empatyczne podejście do tego drugiego stanowiło istotny element Mickiewiczowskiej refleksji o świecie ożywionym (zob. Schollenberger 2010: 36-49).

Z kolei w drugiej połowie XIX wieku osłabienie antropocentryzmu miało przede wszystkim uzasadnienie naukowe. Widać to w różnorodnych tekstach kultury. Bronisław Rejchman, przyrodoznawca i popularyzator teorii Darwina, uwypuklał jej rewolucyjny charakter i zestawiał ją z innymi wielkimi teoriami nauk przyrodniczych: „Kopernik strącił ziemię z wysokiego stanowiska geocentrycznego. Darwin wskazał gatunkowi skromniutkie miejsce pomiędzy miliardami odmian" (Rejchman 1882: 330-331). Konsekwencją Darwinowskiej rewolucji stała się więc zmiana statusu człowieka, który „ze zwaleniem stałości gatunków [ujrzał się - T.S.] efemerą znikomą, jednym z ogniw łańcucha stworzeń" (Rejchman 1882: 330-331).

3 Uwidoczniała się ona również w literaturze i sztukach wizualnych. O „efekcie Darwina” w tych drugich pisuje m.in. Gabriela Świtek (Świtek 2011, 2014). 
Ten proces naturalizacji człowieka wzbudzał sprzeciwy środowisk konserwatywnych. Zwolennicy Darwina skłaniali się ku hipotezie wspólnego pochodzenia organizmów żywych. Zrównanie statusu ludzi i zwierząt nie-ludzkich nie mieściło się jednak jeszcze w horyzontach poznawczych epoki. W 1872 roku opublikowano na łamach „Przeglądu Tygodniowego” studium Feliksa Bogackiego O różnicy człowieka od zwierząt. Autor odwoływał się do ustaleń Darwina i Thomasa Henriego Huxleya, podkreślał załamanie się paradygmatu antropocentrycznego, dostrzegał jednak uprzywilejowaną pozycję człowieka pod względem poznawczym, a więc jako badacza i włodarza przyrody. Instrumentalno-przedmiotowy stosunek gatunku ludzkiego do przyrody skodyfikowany teoretycznie i metodologicznie w przyrodoznawstwie XVI i XVII stulecia, a potem realizowany w ekonomii kapitalizmu - stał się jednym z najistotniejszych składników myślowych antropocenu. Pisząc o upokorzonej przez osiągnięcia nauk przyrodniczych dumie człowieka, Bogacki wszak przekonywał, że praw przyrody tylko on potrafi używać „na swoją korzyść” i dlatego odnosi nad nią zwycięstwo, gdyż przystosowuje do siebie i własnych potrzeb środowisko naturalne (Bogacki 1872: 212).

Bogacki odróżniał człowieka od zwierząt w sposób zbliżony do Kanta. W drugiej połowie XIX wieku etologia zwierząt w zasadzie jeszcze nie istniała (słynna książka Darwina O wyrazie uczuć u człowieka i zwierząt była dopiero jej forpocztą, zresztą sytuowała się w polu psychologii porównawczej), nic przeto dziwnego, że stale posługiwano się utrwalonym stereotypem na temat statusu człowieka oraz jego wyższości nad zwierzętami nie-ludzkimi. Pierwszego charakteryzuje rozumność, krytyczność, język, zdolność do abstrakcji i tworzenia pojęć ogólnych, z kolei zwierzęta to istoty czysto sensualne. Stereotyp ten funkcjonował od czasów Arystotelesa, potem utrwalali go Kartezjusz, Spinoza, Leibniz, Kant ${ }^{4}$.

Choć polski pozytywista akcentował różnice między gatunkiem ludzkim a innymi zwierzętami, to przecież musiał już uwzględnić najnowsze osiągnięcia ówczesnych nauk biologicznych, sankcjonujące naturalistyczną wizję świata, której prawa obowiązywały wszystkie organizmy żywe. O podobieństwie człowieka do zwierząt świadczyły czynniki psychofizjologiczne. Tymczasem w wywodzie Bogackiego pobrzmiewały też echa gatunkowego szowinizmu (gatunkowizmư),

4 Zob. szczegółowe analizy tej kwestii w fundamentalnej monografii Jacka Lejmana (Lejman 2008).

5 Jak wiadomo, termin „gatunkowizm” (speciesism) wynalazł pół wieku temu brytyjski psycholog Richard Dudley Ryder; oznacza on postawy wyższości gatunkowej, uznające prymat własnych (w domyśle: ludzkich) interesów i potrzeb nad interesami innych 
zawarte choćby w twierdzeniu o wyższości człowieka nad zwierzętami, polegającej na tym, że dzieje homo sapiens i jego kultury mają charakter postępowy, gdyż podlegają procesowi doskonalenia się dzięki zacieśnianiu się i rozwojowi stosunków społecznych. Mógł Bogacki zapożyczyć to twierdzenie u Comte’a. Autorytatywnie wyrokował, iż: „Postęp właściwym jest tylko ludzkości” (Bogacki 1872: 212). Wprawdzie zaraz dodawał, że nie sposób zweryfikować tezy o zachodzeniu bądź niezachodzeniu postępu w świecie zwierzęcym - i tym sposobem zasugerował nieprzystawalność hominicznej racjonalności do opisu zachowań zwierzęcych - jednak z przekonaniem orzekał o niemożności odnalezienia celu w życiu zwierząt. Z kolei cel ludzkości pojmował Bogacki w duchu pozytywistycznego utylitaryzmu; uważał mianowicie, iż „ruch dziejowy człowieka można [...] ocenić z punktu korzyści jak podmiotowej, tak też i przedmiotowej, przy czym miarą musi [...] i może być tylko uczucie i zasada korzyści, stawiąca i oceniająca cele ludzkości” (Bogacki 1872: 212). Rzecz jasna, stanowisko takie jawi się dziś jako wyraz świadomości zdeterminowanej historycznie, w konfrontacji z najnowszymi odkryciami nauk przyrodniczych (w tym neurofizjologicznych) okazuje się zaś błędne.

Moralnie kompromitujące - z dzisiejszego punktu widzenia - okazały się rozważania publicysty propagujące skrajnie eksploatatorski stosunek człowieka do przyrody: „Człowiek zrobił już wiele, pozostaje mu wszakże zrobić jeszcze dużo, a mianowicie zaprząc przyrodę jak bydlę do przyrody, zmusić ją, by mu służyła jak niewolnik" (Bogacki 1872: 212).

Zdania te napisał człowiek postępowy, liberalny pozytywista, zwolennik metody naukowej, przeciwnik metafizyki spekulatywnej. Jak widać, nawet i on nie mógł przekroczyć granic światopoglądu antropocentrycznego. Postępowość Bogackiego i innych pozytywistów miała tedy charakter względny. Podmywali oni fundamenty filozoficznego antropocentryzmu w sposób umiarkowany; dostrzegając wspólne cechy ludzi i zwierząt nie-ludzkich, nie mogli się wyzwolić z przekonania o intelektualnej i moralnej wyższości człowieka. Walka pozytywistów z reminiscencjami antropocentryzmu i tradycyjnej (ugruntowanej w znacznej mierze na teologii) metafizyki uwidoczniała się w ich rozważaniach nad duszą ludzką, nad istotą i zadaniami psychologii, nad materialistyczną fizjologią.

Kategoria „duszy” odgrywała w historii metafizyki i antropologii filozoficznej doniosłą rolę od czasów filozofii starożytnej, głównie Platona i Arystotelesa, potem stała się konstytutywnym składnikiem doktryny chrześcijańskiej.

gatunków zwierzęcych. Postawy te stały się obiektem fundamentalnej krytyki ze strony słynnych obrońców praw zwierząt: Petera Singera, Toma Regana, Gary’ego Francione i wielu innych. 
W dualistycznej metafizyce Kartezjusza dusza funkcjonowała jako substytut myśli i (samo)świadomości, przeciwstawiony rozciągłej materii świata przedmiotowego. Miała ona proweniencję boską, przydawała człowiekowi ontycznej wyższości nad zwierzętami i nad materią nieożywioną. Naturalizacja obrazu świata i człowieka wywoływała stopniowe przekształcenia tej skrajnie antropocentrycznej metafizyki. W drugiej połowie XIX wieku zaznaczył się proces swoistej desubstancjalizacji duszy; tradycyjna psychologia o orientacji spirytualistycznej podtrzymywała hipotezę esencjalności tej kategorii, tymczasem fizjologia materialistyczna przeciwstawiała jej mózg funkcjonujący mechanistycznie na podstawie praw fizyko-chemicznych. Toczyły się przy okazji debaty o duszy (psychice) człowieka i zwierząt nie-ludzkich. Istotną rolę odgrywały tu prace Wilhelma Wundta, przede wszystkim jego Wykłady o duszy ludzkiej i zwierzęcej. Antyspekulatywny i antymetafizyczny kierunek psychologii eksperymentalnej sprzyjał niejako odkrywaniu związków między życiem emocjonalnym ssaków, istniała natomiast nieprzekraczalna bariera w pojmowaniu umysłowości człowieka i zwierząt. Tym drugim zasadniczo odmawiano zdolności w tym względzie, podkreślając niższy stopień rozwoju ich świadomości. Wundt położył nacisk na doświadczalne podłoże badań nad duszą (psychiką). Przekonywał zarazem, iż:

Byłoby bardzo szkodliwym, a nawet uwłaczającym naszej umiejętności, jeżeli chcielibyśmy ograniczyć się rozważaniem jedynie duszy ludzkiej [...]. Wszakże i u zwierząt napotykamy objawy świadczące o istnieniu uczucia, wyobraźni, a nawet myślenia (Wundt 1873: 29).

Przyznać trzeba Wundtowi, iż odrzucił wiele antropocentrycznych stereotypów i że w pewien sposób dowartościował zwierzęta, podnosząc ich status. Metafizyczną przesłanką jego wywodu był monizm przyrodniczy, uzasadniający hipotezę o braku ostrych demarkacyjnych linii między gatunkami.

Ważnym motywem rozważań Wundta było nadto pogłębione i rozszerzone ujęcie natury zwierząt nie-ludzkich, przełamujące wcześniejsze - wynikłe w znacznej mierze z uprzedzeń typowo szowinistycznych - stereotypy, według których wyłączną istotą zwierzęcia jest wrodzony instynkt, przejawiający się na płaszczyźnie behawioralnej w postaci reakcji mechanicznych. Zdaniem niemieckiego psychologa: „Błędnym jest bowiem mniemanie, że tworzenie pojęć lub mowa jest wyłącznym przywilejem ludzkości, gdyż [...] u doskonalszych zwierząt istnieją ogólne wyobrażenia [...]” , a ponadto „wiele zwierząt posiada środki wzajemnej komunikacji swych myśli za pomocą dźwięków bądź też za pośrednictwem znaków i rozmaitych gestykulacji” (Wundt 1873: 516). 
Rozpoznanie języków zwierząt traktował Wundt jako istotne zadanie badawcze, które być może da się w przyszłości wykonać.

Stosunkowo złożoną strukturę psychofizjologiczną zwierząt odnajdywali wtedy liczni uczeni zajmujący się psychologią porównawczą. Ich ustalenia miały duże znaczenie dla zmian w postrzeganiu ludzi oraz zwierząt nie-ludzkich, przyczyniając się do rewizji światopoglądu antropocentrycznego i gatunkowego szowinizmu. Dość tu przywołać ważne studium Instynkt $u$ zwierząt i ludzi polskiej biolożki i neurofizjolożki Michaliny Stefanowskiej. Przewodnią myślą tego tekstu była hipoteza przypisująca zwierzętom inteligencję, mylnie, powierzchownie i w sposób stereotypowy nazywaną instynktem. Stefanowska dostrzegła zakotwiczenie tego stereotypu w języku, uważała też, iż zdolności zwierząt i człowieka w dużej mierze zależą od fizjologii mózgu. Nie miała ona wątpliwości, że np. „krasomówczość Gambetty jest tegoż rodzaju, co talent tkacki pająka” (Stefanowska 1891: 31).

W swojej późniejszej książce Miłość macierzyńska w świecie zwierząt (1902) uczona oscylowała między hipotezą o względnie równoważnym statusie ludzi i zwierząt a myśleniem antropocentrycznym. W poczuciu wyższości gatunkowej przekonywała na przykład, że choć każdy obserwator „u zwierząt dostrzeże niektóre uczucia podobne do ludzkich”, to przecież „między człowiekiem a zwierzęciem zawsze pozostanie przepaść niezgłębiona, gdyż Bóg obdarzył człowieka duszą nieśmiertelną" (Stefanowska 1902: 3). Ta silna deklaracja metafizyczna wybrzmiała na samym wstępie książki, później autorka już nie nawiązywała do niej. Jej opisy behawioru zwierząt, skupione na objawach miłości matek w stosunku do potomstwa ${ }^{6}$, były nasycone antropomorfizacją. Uczona z jednej strony przekonywała o konieczności poznawania życia zwierzęcego, upominała się o zmianę stosunku ludzi do zwierząt i - tym samym - eliminację wrogości i pogardy człowieka dla nich, z drugiej jednak - odwołała się do kulturowego przesądu o ewidentnie szowinistycznym wydźwięku. Przejawił się on w uwagach o przebiegłości samic niektórych gatunków, dzięki której w wielu przypadkach „człowiek nie jest w stanie wytępić szkodliwych dla siebie zwierząt” (Stefanowska 1902: 64). Przyzwolenie na ludzkie okrucieństwo zostało tu niemal zrównane z odruchem bezwarunkowym.

Jak trudno było przełamywać zapory antropocentryzmu i szowinizmu gatunkowego, świadczy artykuł Władysława Kozłowskiego O samobójstwie zwierząt z 1884 roku. Poczucie wyższości wobec zwierząt przenika strukturę tego tekstu. Pomimo pozorów obiektywizmu i osadzenia wywodów na odpowiednio

6 Autorka uwzględniła zachowania samic ssaków, ptaków, gadów, owadów, skorupiaków, przyrównując je do doświadczeń ludzkich. 
dobranych wynikach badań psychologii porównawczej Kozłowski usilnie przekonywał, iż samobójstwo jako akt moralny i rozumowy jest poza zasięgiem natury zwierzęcej. W stanowisku autora przejawiały się typowe dla większości ówczesnych dyskursów o zwierzętach i ich relacjach z ludźmi sprzeczności. Stopień akceptacji zwierząt - podobnie jak w wielu innych głosach z tamtej epoki - zależał od tego, czy i w jakiej mierze wykazywały one cechy ludzkie bądź do ludzkich zbliżone.

Podobnie jak wielu innych antropocentrycznych pozytywistów, Kozłowski widział wyższość gatunku ludzkiego nad innymi zwierzętami w zdolności tworzenia zbiorowisk kulturowych, czyli społeczeństw. W przeciwieństwie do ludzkich związki grupowe zwierząt są „bardzo proste i nierozwinięte, obrachowane głównie [...] na najnaglejsze potrzeby życia, którego naczelnym zadaniem jest zachowanie bytu osobnika i gatunku" (Kozłowski 1884: 282). Kozłowski - nawiązujący zresztą w swoich wywodach do książki Animal Intelligence (1878) George’a Romanesa - nie mógł przystać na to, by motywy zwierząt popełniających samobójstwo mogły być czymś więcej niż przejawem zaburzonego instynktu samozachowawczego. U zwierząt domowych bądź przebywających w niewoli wytwarzały się z kolei „nowe uczucia, czysto towarzyskie, których zaspokojenie staje się dla nich potrzebą tak gwałtowną, że może ona zapanować i przygłuszyć sam popęd samozachowawczy" (Kozłowski 1884: 294), co kończyło się niekiedy śmiercią. Kompromitujący publicystę szowinizm gatunkowy - wówczas jednak niedostrzegany i niejako naturalny - przejawiał się na językowym poziomie jego wywodu, gdy pisał on o „zdychaniu” zwierząt (choćby psów umierających z żalu za utraconym panem)7. To była powszechna wtedy praktyka retoryczna; funkcjonuje ona do dzisiaj. Bodaj pierwszym polskim myślicielem, który ją dostrzegł i potępił, był Marian Zdziechowski, autor wydanej w 1928 roku wstrząsającej książki O okrucieństwie ${ }^{8}$.

Samoświadomość podmiotowa, język, racjonalność, zdolność do abstrakcji i predykcji, tworzenie kultury w sposób kumulatywno-progresywny - to cechy dystynktywne kondycji ludzkiej, nieustannie podnoszone w dziewiętnastowiecznym dyskursie o człowieku i zwierzętach, zdominowanym przez myślenie binarne i esencjalistyczne. Jeśli w drugiej połowie XIX wieku powszechnie akceptowano tezy o anatomicznym i fizjologicznym podobieństwie człowieka do zwierząt, przede wszystkim do ssaków naczelnych (prymatów), a nawet

7 Pogardliwy czasownik „zdychać”, używany przez człowieka w odniesieniu do zwierząt, w sposób drastyczny ujawnia jego poczucie gatunkowej wyższości. Zob. Stanisławski 2015: 81; Gzyra 2015: 73-108.

8 Znaczenie tej publikacji podkreślił Włodzimierz Tyburski (Tyburski 2013: 59-60). 
odnajdywano podobieństwa behawioru między homo sapiens a małpami człekokształtnymi, to jednak nawet zwolennicy monizmu naturalistycznego i teorii Darwina podkreślali wyższy stopień rozwoju człowieka i jego znacznie większe możliwości poznawcze. Zresztą pogląd taki głosił sam autor $O$ pochodzeniu gatunków. Jego wierny stronnik Huxley pisał znamiennie: „człowiek, przemieniwszy swoją surową naturę, stoi obecnie jakby na szczycie góry, wyniesiony nad poziom niższych stworzeń" (Huxley 1874: 98).

Dystans między człowiekiem a nawet pokrewnymi mu zwierzętami wydawał się więc nie do zniwelowania. Uderzające, jak silny był wpływ tej antropocentrycznej tradycji myślowej, skoro ulegali jej nawet wyznawcy monizmu naturalistycznego i ewolucjonizmu. Przyznać jednak trzeba, iż to właśnie w tych środowiskach zaczęto dostrzegać cierpienia zwierząt i konieczność zmiany podejścia ludzi do nich. W nieodległej tradycji filozoficznej duże znaczenie miały poglądy Jeremy’ego Benthama i Arthura Schopenhauera, którzy widzieli w zwierzętach istoty doznające cierpienia i postulowali (względnie) podmiotowy stosunek do nich. W drugiej połowie XIX wieku - w okresie dynamicznie rozwijającego się kapitalizmu - zwierzęta były jednak obiektem brutalnej eksploatacji i wyzysku, na co zwracali uwagę np. polscy pozytywiści i naturaliści. Nie znaczy to, że zrównywali oni status człowieka ze zwierzętami nie-ludzkimi ani że konsekwentnie postulowali ekologizm. Z całą jednak stanowczością wystąpili w obronie zwierząt, widzieli w nich istoty czujące i cierpiące, przeciwstawiali się wszelkim przejawom okrucieństwa w stosunku do nich. Trzej zwłaszcza pisarze i publicyści wyróżnili się w tym gronie: Bolesław Prus, Aleksander Świętochowski i Adolf Dygasiński. Wszyscy - w mniejszym lub większym stopniu - byli zwolennikami Darwina, najgorętszym bodaj ten ostatni.

Dygasiński-publicysta usilnie propagował założenia teorii Darwinowskiej, z kolei w twórczości artystycznej kreował obraz świata, w którym wszystkie gatunki współistnieją i podlegają działaniu tych samych praw: dziedziczności i doboru naturalnego. Pisarz zawsze zabiegał o podmiotowy stosunek do zwierząt, ukazywał ich skomplikowane życie psychiczne, podatność na cierpienie i doznawanie bólu. Był spośród pisarzy polskich drugiej połowy XIX wieku najwybitniejszym etologiem zwierząt. Twórczość jego posłużyła niedawno Annie Barcz w jej eko- i zookrytycznych interpretacjach literatury polskiej tamtego okresu. Dość tu przywołać świetne, nowatorskie odczytanie opowiadania Niezdara, w którym autorka dostrzegła przejawy sprawstwa przyrody (Barcz 2016: 139-154). Ogólnie biorąc, Dygasiński odegrał kluczową w literaturze polskiej rolę pisarza i myśliciela promującego nastawienie (proto)ekologiczne. Duże znaczenie miała też tworzona przezeń wizja wspólnoty natury, w której człowiek, zwierzęta i przyroda współistnieją ze sobą i gdzie związki 
emocjonalne - podkreślające równość wielu podmiotów - odległe były od dominacji silniejszego (czyli człowieka).

Etyczne podejście do kwestii zwierzęcej silnie się zaznaczyło w pracach Aleksandra Świętochowskiego. Ten najwybitniejszy publicysta z kręgu polskich pozytywistów wykazywał się wielką wrażliwością w stosunku do zwierząt. Przejmujący wyraz znalazło to w noweli Woły (1885) oraz w obszernym, wstrząsającym studium Moralność wobec zwierząt (1879), w którym demaskował bezwzględne i okrutne metody wiwisekcji. Świętochowski stanowczo upominał się o podmiotowy, pełen szacunku i troski stosunek do zwierząt. Oburzało go ludzkie okrucieństwo i skrajne przejawy szowinizmu gatunkowego. Nie mógł się pogodzić ze stanowiskiem „wszechwładztwa ludzkiego”, które przedmiotowe traktowanie zwierząt uzasadniało ich niższym statusem $\mathrm{w}$ porównaniu z gatunkiem ludzkim. Było to - zdaniem Świętochowskiego - podejście niewłaściwe, skompromitowane moralnie, sprzeczne z głoszoną przezeń zasadą etyki ekstensywnej. Publicysta powoływał się na najnowsze odkrycia nauk eksperymentalnych, które merytorycznie uzasadniały hipotezy podmiotowości zwierząt, akcentując np. ich inteligencję. Był przekonany, że obowiązująca etyka - ufundowana na metafizycznej iluzji wyższości człowieka - ,jest tylko protegowaniem własnego gatunku” (Świętochowski 1879, nr 133: 1).

Doniosłe znaczenie miały w wywodzie Świętochowskiego argumenty wymierzone przeciwko niehumanitarnej koncepcji zwierzęcia maszyny i związanemu z nią czysto utylitarnemu podejściu do istoty żywej przecież, a traktowanej w sposób bezduszny i bezwzględny jako obiekt eksploatacji. Z nieukrywanym żalem oznajmiał:

Wrażliwość zwierzęcia jest tak słabo uwzględnianą, że gdyby ktoś z gniewu zabił pięknego konia, świadkowie tego czynu dziwiliby się raczej głupocie mordercy, który się użytecznego stworzenia pozbawił, niż okrucieństwu, które śmiercią ofiary się nasyciło. Wszelkie bowiem zwierzę posiadane jest w oczach ogółu tylko przedmiotem własności, którym dowolnie rozporządzać można (Świętochowski 1879, nr 133: 2).

Świętochowski skupił się w swoim studium na problemie wiwisekcji zwierząt, rozpatrując ją z punktu widzenia moralnego i naukowego. Problem ten wywoływał w drugiej połowie XIX wieku - i wywołuje do dziś - ogromne kontrowersje. Można by go potraktować jako skrajny przypadek szowinizmu gatunkowego, który przejawiałby się tu - jak to ujmuje Peter Singer - w traktowaniu zwierząt w sposób taki, który byłby niedopuszczalny w stosunku do ludzi (Singer 2018: 72). Wielu dziewiętnastowiecznych uczonych, myślicieli, 
lekarzy występowało przeciwko okrucieństwom wiwisekcji; prym wiedli tutaj Brytyjczycy, wyróżniali się też Niemcy. Świętochowski z uznaniem odniósł się np. do postawy niemieckiego pisarza Ernsta von Webera, który w 1879 roku założył stowarzyszenie działające przeciwko wiwisekcyjnym torturom na zwierzętach. Czarną listę eksperymentatorów tworzyli m.in.: François Magendie, Claude Bernard, Charles Blagden, Jean-Baptiste Bouillaud, Éugène Magnan, Moritz Schiff, William Carpenter, John Burdon-Sanderson, Hermann Nothnagel. Świętochowski nie oszczędził czytelnikowi przerażających opisów wiwisekcji zwierząt, przytaczając przy okazji szokująco bezduszny sąd głośnego eksperymentatora Emanuela Kleina: „Fizjologiczny eksperymentator, którego cała uwaga zajęta jest naukową stroną doświadczenia, nie ma ani czasu, ani chęci kłopotać się tym, co poświęcone na ofiarę zwierzę czuje" (Świętochowski 1879, nr 135: 2).

$\mathrm{W}$ opinii przywódcy polskiego pozytywizmu argumenty zwolenników wiwisekcji na zwierzętach nie wytrzymywały krytyki. Odrzucał więc ich postulaty całkowitej wolności badań naukowych oraz zapewnienia, że wiwisekcje umożliwiły dokonanie odkryć niedostępnych badaniom innego rodzaju. Wspierał się przy tym opiniami wielu uczonych i lekarzy przeciwstawiających się wiwisekcjom: Herkulesa Straus-Durkheima, Charlesa Bella, Augusta Nélatona, Williama Fergussona, Carla von Rokitansky'ego, Friedricha Goltza. Przywołał nawet zdanie Darwina potępiające wiwisekcję, tyle że nie było to w pełni zgodne ze stanowiskiem wielkiego uczonego, który postęp badań naukowych wiązał wszak $\mathrm{z}$ eksperymentami wiwisekcyjnymi, ale - uwrażliwiony na cierpienia zwierząt, zwłaszcza psów - domagał się ich odpowiednich regulacji oraz wykorzystywania środków anestezjologicznych (wiwisekcje bez znieczulenia stanowczo potępiał, czemu dał wyraz w swoim wystąpieniu przed Komisją Królewską w listopadzie 1875 roku) 9 .

Debata nad wiwisekcją zwierząt angażowała wielu uczestników głównie w Wielkiej Brytanii i Niemczech. Świętochowski poruszał sumienia i uczucia odbiorców obrazami „strasznej martyrologii zwierzęcej”, nie ukrywał swojej zdecydowanej niechęci do wiwisekcji, uważał, iż korzyści z niej płynące nie wyrównują krzywdy i cierpień zwierzą $t^{10}$. Rzecz znamienna przy tym: sformu-

9 Skomplikowany stosunek Darwina do wiwisekcji, rozpięty między współczuciem dla zwierząt a chęcią obrony przyjaciół uczonych, pochopnie - jego zdaniem - oskarżanych o okrutne postępowanie ze zwierzętami, omawia David A. Feller (Feller 2009: 265-271). Zaangażowanie Darwina w dyskusje o wiwisekcji oraz w prace parlamentarne nad ustawą wiwisekcyjną przedstawia artykuł Darwin and vivisection.

10 W Polsce głos w sprawie wiwisekcji zabrał w 1910 roku Adam Wrzosek. Uczony ten usprawiedliwiał dokonywanie wiwisekcji argumentami naukowymi. W zakończeniu 
łował on myśl zgoła wyprzedzającą własną epokę, ze zdumiewającą przenikliwością przewidywał bowiem możliwość gruntownych przemian świadomości, w wyniku których człowiek miałby się wyzbyć szowinistycznego poczucia wyższości nad innymi gatunkami i całą naturą. Rozważając zakaz zabijania ludzi, wyprowadzał zeń określone konsekwencje dla relacji: człowiek - zwierzę i człowiek - natura:

Dopóki [człowiek - T.S.] łudzić się może, że zwierzę jest organizmem nieczułym i bezrozumnym, potrzebuje tylko oszczędzać ludzi, ażeby być z zakazem w zgodzie. Ale co zrobi, gdy mu nauka powie, że to zwierzę ma w niższym stopniu takież jak i on władze umysłowe? Co zrobi, gdy się kiedyś przekona, że pierwiastki duchowe tkwią również w roślinach i minerałach? Czy wtedy poświęci siebie na ofiarę wszechświatowej sprawiedliwości? Czy się zagłodzi dla dobra moralności, którą sam stworzył i na całą naturę rozciągnął? (Świętochowski 1879, nr 142: 1).

Pomimo swojej postępowości i empatii do zwierząt publicysta otwarcie przyznawał, iż rzeczą bardzo trudną - chyba wręcz niemożliwą - jest wyzwolenie się z oków etyki ludzkiej. Człowiek, jako gatunek najbardziej w ewolucji rozwinięty, górował nad innymi zwierzętami. Zjadał je i poddawał eksperymentom wiwisekcyjnym. Świętochowski ubolewał nad dogmatyzmem moralności skrajnie antropocentrycznej, zasugerował jej przekroczenie, stwierdzając, że „nie ma żadnej słusznej racji zamykania praw moralnych jedynie w obrębie stosunków człowieka do człowieka”. Niestety - dodawał - człowiek „nie chce przyznać zwierzętom nietykalnego przywileju życia i zabijając je na pokarm, tym samym pozwala zabijać dla badań naukowych" (Świętochowski 1879, nr 142: 1).

Protest Świętochowskiego przeciwko okrucieństwu wiwisektorów i nieuregulowanym prawnie oraz proceduralnie wiwisekcjom to jeden z najpiękniejszych głosów w polskich dyskusjach o relacji: człowiek - zwierzę nie-ludzkie w drugiej połowie XIX wieku. Publicysta poruszał się jeszcze w epistemicznych ramach

swoich wywodów zaprezentował się jako zwolennik scjentyzmu, przedkładający metody i cele poznania naukowego nad cierpienie zwierząt: „[...] w imię wolności badania naukowego należy zwalczać przeciwników wiwisekcji jako ludzi, którzy chcą wyrządzić szkodę nauce, choć nieraz nie uświadamiają sobie tego dokładnie, że walcząc przeciw wiwisekcji, walczą przeciw wolności badania i przeciw wolności nauczania na uniwersytetach" (Wrzosek 1910: 20). Z dzisiejszego punktu widzenia broszura Wrzoska stanowi wyraz szowinizmu gatunkowego. Także współcześnie kwestia ta wzbudza ogromne kontrowersje. Zdecydowany głos przeciwko wiwisekcji wybrzmiał w książce Richarda Dudleya Rydera (1983), zob. też Ryder 2011. 
antropocenu, widząc w rozwoju uczuć moralnych człowieka w stosunku do zwierząt kryterium jego wartości cywilizacyjnej (np. lud wiejski swój niski poziom kulturowy poświadczał okrucieństwem wobec zwierząt). Podejście Świętochowskiego do zwierząt, empatyczne i (względnie) podmiotowe, mieściło się w ramach stanowiska welfarystycznego, które było charakterystyczne dla dziewiętnastowiecznych towarzystw opieki nad zwierzętami. Stanowisko to charakteryzował "pogląd głoszący, że dobrostan zwierząt ma znaczenie w sensie moralnym, ale też jest on podporządkowany interesom ludzi” (Donaldson, Kymlicka 2018: 15) ${ }^{11}$.

Ale nie sposób odmówić Świętochowskiemu umiejętności przynajmniej częściowego wykroczenia poza antropocentryzm. Zdawał on sobie sprawę ze ścisłej współzależności człowieka i zwierząt, dostrzegał ogromny wkład tych drugich w rozwój kultury ludzkiej, pisał o ich wielorakim poświęceniu dla człowieka w jego rozwoju ewolucyjnym. „Skazaliśmy mnóstwo gatunków zwierzęcych na ofiarę dla naszego żołądka, a nie zrobiliśmy prawie nic, co by im to poświęcenie złagodzić mogło" (Świętochowski 1879, nr 146: 1) - pisał. I domagał się dla zwierząt zarówno miłosierdzia, jak i sprawiedliwości. Zwierzęta czują, cierpią, pracują dla człowieka, są przezeń brutalnie wykorzystywane, służą mu za pokarm. Człowiek musi zmienić swoje podejście do nich; nie może i nie powinien bezwzględnie wykorzystywać swojej przewagi nad nimi. Wprawdzie sformułowanie „wspólnota” w rozważaniach Świętochowskiego się nie pojawiło, niemniej z jego wywodów wynikał postulat zerwania przez człowieka z postawą właściwą szowinizmowi gatunkowemu.

Los zwierząt przeznaczonych na pokarm - w dobie gwałtownie rozwijającego się kapitalizmu i społeczeństwa masowego po prostu utowarowionych i traktowanych jako rzeczy, przedmioty nieożywione - wzbudzał autentyczne współczucie publicysty. Z oburzeniem piętnował on okrutne obchodzenie się z nimi w rzeźniach i w transporcie (współcześnie te szokujące praktyki przedstawił w ujęciu historycznym Éric Baratay (zob. Baratay 2018: 155-166)). W zakończeniu studium raz jeszcze podniósł argument naukowy: odkrycia przyrodoznawstwa dowodnie poświadczały zdolność odczuwania u zwierząt i ich podobieństwo do ludzi także od strony psychologicznej. Toteż - przekonywał - „nie mamy żadnego powodu wątpić, że przywiązany w szlachtuzie wół, widząc jak pod uderzeniem młota padają z jękiem jego towarzysze, czekając kolei śmierci, doznaje najstraszniejszych męczarni [...]" (Świętochowski 1879,

11 Charakterystykę dwu nurtów obrońców praw zwierząt: reformistycznego (welfarystycznego) oraz abolicjonistycznego przynosi w polskiej literaturze przedmiotu książka Doroty Probuckiej (2013). 
nr 146: 1). W zdecydowanej większości ludzie są tego dramatu nieświadomi lub podchodzą do niego obojętnie. W noweli Woły z 1886 roku pisarz przedstawił brutalnie przedmiotowy i utylitarny stosunek człowieka do tych zwierząt (por. Piechota 2018: 114-117). Współczucie dla ich cierpień opatrzył autor pytaniem o możliwość istnienia człowieka bez zadawania bólu zwierzętom, bez eksploatacji i mordowania ich. Finał noweli ma wydźwięk pesymistyczny: gatunek ludzki wyłącznie warunkowo i wyjątkowo przyznaje zwierzętom prawo do istnienia, do opieki, do współczucia. To zaś zwierzę, które na rzeź przeznacza i zjada, „zasługuje tylko na okrucieństwo” (Świętochowski 1965: 196). Głęboka intencja etyczna kierowała pisarzem, gdy obrazował cierpienia wołów skazanych na śmierć:

Czy kiedykolwiek przypatrzyłeś się im, czytelniku? Jak smutnie spoglądają ich duże, bolesnym przeczuciem zaćmione oczy! Boki zapadłe, skóra wypalonymi stemplami oznaczona, w całej postaci rozlana niema rozpacz. Dźwigają swe mięso na ofiarę człowiekowi, który nie ma dla nich litości. Ile razy przechodzę koło gromadki tych płowych skazańców wiedzionych na śmierć, serce mi się ściska strasznym kurczem (Świętochowski 1965: 196).

Z dużą wrażliwością etyczną podchodził do losu wołowatych także Bolesław Prus. Jego stosunek do zwierząt, „starszych (lub młodszych) braci w Darwinie” (tak je nazywał), oraz refleksje nad relacjami: człowiek - zwierzęta nie-ludzkie zasługiwałyby na oddzielne opracowanie. Można by podejście Prusa określić jako zarówno empatyczne, jak i antropocentryczne. Pisarz był wrażliwy na cierpienia każdej istoty żyjącej, zwierzęta lubił, cenił, podziwiał, apelował o humanitarne podejście do nich, piętnował wszelkie przejawy okrucieństwa wobec nich. Nie zdołał jednak wykroczyć poza stanowisko antropocentryczne, był bodaj bardziej zachowawczy aniżeli Świętochowski. Dobrostan człowieka uznawał za priorytet, podporządkowywał mu los zwierząt. Gdy jednak los zwierzęcia wymagał interwencji, Prus natychmiast zabierał głos. W 1879 roku dowodem ludzkiej „dzikości i zbrodni” było dlań traktowanie krów, byków i cieląt na targu praskim. Oburzony barbarzyńskim okrucieństwem człowieka, upominał się o poszanowanie zwierząt oraz - przynajmniej - o ulżenie ich doli:

„Ależ te biedaki czują, co się z nimi dzieje!... Czują głód, pragnienie, zimno, ciasnotę, deszcz lub śnieg padający z góry, kałużę pod nogami i bezsenność a niemożność wypoczynku. Wszakże i w tych długich, łagodnych głowach tleje jakaś myśl, jakieś wspomnienia, trwoga, żal”. 
Jeżeli los skazał nas na pożeranie istot żyjących, nie dręczmyż ich przynajmniej, a jeżeli wznieśliśmy się do współczucia, do opieki nad zwierzętami, pełnijmyż ją (Prus 1955: 142).

Postępowanie ludzi wobec zwierząt wielokrotnie dawało Prusowi sposobność do zapisywania uwag natury ogólniejszej, dotyczących statusu homo sapiens i nadużyć, jakich dopuszczał się on w stosunku do zwierząt nie-ludzkich i całej natury. Zdarzało się pisarzowi poruszać etyczne konsekwencje gatunkowizmu. Czasem wyczuwał on nieuzasadnioną dominację człowieka zaburzającą względnie harmonijne relacje między różnymi gatunkami w świecie naturalnym. Komentując propozycje postulujące bardziej humanitarne obchodzenie się ze zwierzętami maltretowanymi przez ludzi w mieście oraz pomysł stworzenia przytułku, w którym mogłyby być one „zabijane bez cierpień”, pisał w swoim stylu, nie bez ironii i goryczy:

Powiedz, bawole, tułający się bez „opieki” po indyjskich lasach, jak $\mathrm{z}$ tobą postępuje tygrys?... Czy zaprzęga cię do pracy, czy kaleczy kark jarzmem, czy obija boki batami lub kijami?... Czy okrada cię na żywności, czy więzi cię w obrzydłej oborze, czy naraża cię na złamanie nogi?... Czy przewozi ciebie, głodnego i znękanego, bez siana i wody o kilkadziesiąt mil na targi?... Czy pędzi cię okaleczonego do szlachtuza, czy mordując twoich braci wołów, każe ci w trwodze oczekiwać na straszną kolej?...

Nie. Tygrys nagle wyskakuje z zasadzki i rzuca się na ciebie. Jeżeli jesteś silny i roztropny, cofa się przed twoimi rogami, a dopiero, jeżeliś słaby i lekkomyślny, chwyta cię za gardło i dusi w jednej chwili.

Nie tygrys to wynalazł baty, jarzma i obory. Nie tygrys pozbawia cię słodkiego uczucia miłości. Nie tygrys głodzi cię i kaleczy. Wszystko to robi dopiero - człowiek, najprzedniejsze po aniołach stworzenie Boskie. Ach, mój biedny wole, jak byś ty strzelał z palców, wydobywszy się spod „opieki” człowieka i „stawszy się pastwą dzikich zwierząt!...” (Prus 1960: 179).

Prus niedwuznacznie tu zasugerował moralną deprawację człowieka, który we własnym mniemaniu i na mocy tradycji kulturalnej przyznawał sobie nieograniczone prawo do dominacji nad światem nie-ludzkim. Nie oznaczało to jeszcze przekroczenia przez pisarza granic świadomości antropocentrycznej, $\mathrm{w}$ wielu bowiem sytuacjach stanowczo się upominał o interesy ludzi, stwierdzając, iż należą one do „ważniejszych potrzeb społecznych” aniżeli prawa zwierząt. 
Interesującym wątkiem jego rozważań była próba socjokulturowej analizy działań warszawskiego Towarzystwa Opieki nad Zwierzętami oraz spodziewanego przezeń rozwiązania tej instytucji. Przyczyn jej (rzekomego) niepowodzenia upatrywał w nieprzystawalności do oczekiwań ogółu, które dotyczyły przede wszystkim spraw ludzkich. O ile interesy zwierząt były dla większości „błyszczącym piórkiem”, swoistą fanaberią wąskiej elity intelektualnej, o tyle potrzeby ludzkie niezmiennie stanowiły priorytet (zob. Prus 1955: 177-178). Z punktu widzenia świadomości dzisiejszej humanistyki środowiskowej skłaniał się on tutaj ku szowinizmowi gatunkowemu.

Jak wiadomo, w postulowanym przez siebie programie społecznym Prus stał na gruncie socjologii naturalistycznej i postrzegał świat ludzki jako część makrokosmosu natury. W jego wizji występowało relacyjne ujęcie wszystkich organizmów żywych oraz materii nieożywionej; różne podmioty i przedmioty współistniały ze sobą, wymieniając się „usługami”. Nieodległe to było myślenie od stanowiska samego Darwina, akcentującego ścisłe powiązania międzygatunkowe, „współ-bycie” człowieka i zwierząt nie-ludzkich w świecie, a także zacierającego granice między różnymi podmiotami, co przejawiało się m.in. w zabiegach materializacji człowieka oraz rewaloryzacji dżdżownic (Schollenberger 2020: 432-449). Prus, dysponujący tylko ogólną wiedzą zoologiczną, swoje spojrzenie na wspólnotę organiczną łączył ze zdecydowaną krytyką eksploatatorskiego podejścia Polaków do zasobów naturalnych i zwierząt.

Czy w stosunku do naszej ziemi - zapytywał - pilnujemy się zasady „wymiany usług”? Nie - i żadnym dla nas nie może być tłumaczeniem, że inni robią jeszcze gorzej. Gdy przypomnimy sobie, że [...] nasze pola są źle uprawiane, że lasy wycinamy, lecz nie pielęgnujemy, że wody są nieuregulowane ani zarybione, że tępimy dziką zwierzynę, że łamiemy drzewa przy drogach zamiast je sadzić, że nasze zwierzęta domowe bezwstydnie wyzyskujemy, okaże się, iż postępowanie nasze z naturą jest - złe. Tu nie ma wymiany usług, tu jest rabunek (Głowacki 1883: 19).

Widać w tym wywodzie przejaw wnikliwej samoświadomości Prusa, który odpowiedzialnością za dewastacyjne zmiany w naturze obciążył gatunek ludzki. Tego rodzaju uwagi formułował on niejednokrotnie; rzec można, iż wyczuwał etyczne kontrowersje antropocenu. Wszakże stworzona przez Prusa teoria „najogólniejszych ideałów życiowych” - doskonałości, użyteczności i szczęścia - miała charakter antropocentryczny, odnosiła się przede wszystkim do spraw ludzkich, jednak uwzględniała też relacyjność bytu. Pisał bowiem Prus: „Cała [...] natura jest Związkiem o niedającej się pojąć wielkości i komplikacji” 
(Prus 1901: 48). Choć człowiek miał tu pozycję dominującą, to jednak powinien z troską i współczuciem odnosić się do innych istot żywych oraz do całej natury. Wstrząśnięty okrutnym traktowaniem zwierząt i brutalną eksploatacją ziemi i zasobów naturalnych, postulował Prus, by utworzyć „Towarzystwo Przyjaciót Natury, które czuwałoby nad szczęściem nie tylko zwierząt, nie tylko roślin, ale nawet ziemi, lasów, stawów itp." (Prus 1901: 134-135).

Postawa Prusa - pełna wahań, niekonsekwencji, ale i krytycyzmu wobec szowinistycznych praktyk własnego gatunku - kondensuje w sobie dylematy, złożoność i niekonsekwencje dyskursu (około)zwierzęcego, ukazując napięcia, jakie przenikały refleksje nad relacjami człowieka i zwierząt nie-ludzkich w drugiej połowie XIX wieku. Podejmowane wtedy próby wyłomu w antropocentryzmie i szowinizmie gatunkowym zapoczątkowały proces, który trwa do dziś, przy czym dopiero współcześnie został on opracowany koncepcyjnie. Niekwestionowaną zasługą myślicieli, uczonych i filozofów z czasów Darwina była etyczna i naukowa rewizja paradygmatu wiedzy antropocentrycznej, pozwalająca dostrzec, dowartościować i uznać prawa istnień innych aniżeli homo sapiens.

\section{| Bibliografia}

Baratay Éric (2018), Zwierzęcy punkt widzenia. Inna wersja historii, przeł. Paulina Tarasewicz, Wydawnictwo w Podwórku, Gdańsk.

Barcz Anna (2016), Realizm ekologiczny: od ekokrytyki do zookrytyki w literaturze polskiej, „Śląsk” Wydawnictwo Naukowe, Katowice.

Bogacki Feliks (1872), Ze świata wiedzy. O różnicy człowieka od zwierząt, „Przegląd Tygodniowy", nr 27, s. 212.

Darwin and vivisection, https://tinyurl.com/2vht65da [dostęp: 18.01.2021].

Donaldson Sue, Kymlicka Will (2018), Zoopolis. Teoria polityczna praw zwierzat, przeł. Maria Wańkowicz, Michał Stefański, Oficyna 21, Warszawa.

Du Bois-Reymond Emil (2011), Darwin und Kopernicus. Ein Nachruf, w: tenże, Reden von Emil Du Bois-Reymond, t. 2, red. Sven Dierig, Olms-Weidman, Hildesheim-Zürich-New York (Nachdruck der Ausgabe Leipzig 1912), s. 243-248.

Feller David Allan (2009), Dog fight: Darwin as animal advocate in the antivivisection controversy of 1875 , ,Studies in History and Philosophy of Biological and Biomedical Sciences", t. 40, s. 265-271.

Głowacki Aleksander (1883), Szkic programu w warunkach obecnego rozwoju społeczeństwa, W Drukarni „Gazety Handlowej”, Warszawa. 
Gzyra Dariusz (2015), Speciesism, veganism, carnism... Luki leksykalne jako luki etyczne. W poszukiwaniu niewinnego jezyka, w: Po humanizmie. Od technokrytyki do animal studies, red. Zuzanna Ładyga, Justyna Włodarczyk, Wydawnictwo Naukowe Katedra, Gdańsk, s. 73-108.

Huxley Thomas Henry (1874), Stanowisko człowieka w przyrodzie. Trzy rozprawy, z niemieckiego przekładu J.W. Carusa spolszczył Stefan Żaryn, Nakładem Redakcji „Przeglądu Tygodniowego”, Warszawa.

Kozłowski Władysław (1884), O samobójstwie zwierząt, „Prawda”, nr 24, s. 282-283, nr 25, s. 293-294.

Lejman Jacek (2008), Ewolucja ludzkiej samowiedzy gatunkowej. Dzieje prób zdefiniowania relacji człowiek - zwierze, Wydawnictwo UMCS, Lublin.

Mayr Ernst (2011), Filozoficzne podstawy darwinizmu, przeł. P. Łoś, „Przegląd Filozoficzno-Literacki”, nr 2-3, s. 27-35.

Mytych-Forajter Beata (2017), Zwierzęta na zakręcie, IBL PAN, Warszawa.

Piechota Dariusz (2018), Pozytywistów spotkania z natura. Szkice ekokrytyczne, Wydawnictwo Naukowe Katedra, Gdańsk.

Probucka Dorota (2013), Filozoficzne podstawy idei praw zwierząt, Universitas, Kraków.

Prus Bolesław (1901), Najogólniejsze ideały życiowe, Druk. Tow. Akc. S. Orgelbranda Synów, Warszawa.

Prus Bolesław (1955), Kroniki, t. 4, oprac. Zygmunt Szweykowski, PIW, Warszawa.

Prus Bolesław (1960), Kroniki, t. 11, oprac. Zygmunt Szweykowski, PIW, Warszawa.

Rejchman Bronisław (1882), Teoria Darwina w stosunku do nauki i życia, „Ateneum", t. 3, z. 8, s. 330-357.

Ryder Richard Dudley (1983), Victims of Science: the Use of Animals in Research, National Anti-Vivisection Society Ltd., London.

Ryder Richard Dudley (2011), Szowinizm gatunkowy w laboratoriach, w: W obronie zwierzat, przeł. Monika Betley, red. Peter Singer, Wydawnictwo Czarna Owca, Warszawa, s. 128-151.

Schollenberger Justyna (2010), „Wejść między sforę” - projekt duchowości zwierząt: Mickiewicz - Emerson, „Wiek XIX: Rocznik Towarzystwa Literackiego imienia Adama Mickiewicza”, z. 3, s. 36-49.

Schollenberger Justyna (2020), Stworzenia Darwina. O granicy człowiek-zwierze, IBL PAN, Warszawa.

Singer Peter (2018), Wyzwolenie zwierząt, przedm. Yuval Noah Harari, przeł. Anna Alichniewicz, Anna Szczęsna, Wydawnictwo Marginesy, Warszawa.

Stanisławski Emil (2015), Korzenie szowinizmu gatunkowego, w: Emancypacja zwierząt?, red. Eugenia Łoch, Agnieszka Trześniewska, Dariusz Piechota, Lubelskie Towarzystwo Naukowe, Lublin, s. 73-84. 
Stefanowska Michalina (1891), Instynkt u zwierząt i ludzi, „Ateneum”, t. 3, z. 1, s. 23-32.

Stefanowska Michalina (1902), Miłość macierzyńska w świecie zwierzęcym, Druk J. Sikorskiego, Warszawa.

Świętochowski Aleksander (1879), Moralność względem zwierząt, „Nowiny”, nr 133, s. 1-2; nr 135, s. 2; nr 137, s. 1; nr 139, s. 1-2; nr 142, s. 1; nr 144, s. 1; nr 146, s. 1.

Świętochowski Aleksander (1965), Woły, w: tenże, Nowele i opowiadania, wybór, oprac. Samuel Sandler, Zakład Narodowy im. Ossolińskich, Wrocław.

Świtek Gabriela (2011), Darwin, darwinizm i kultura wizualna XIX wieku, „Teksty Drugie", nr 3, s. 64-82.

Świtek Gabriela (2014), Małpiarnia malarza. Darwinizm w twórczości Gabriela von Maxa, „Wiek XIX. Rocznik Towarzystwa Literackiego imienia Adama Mickiewicza”, r. VII (XLIX), s. 311-321.

Tyburski Włodzimierz (2013), Dyscypliny humanistyczne i ekologia, Wydawnictwo Naukowe UMK, Toruń.

Wrzosek Adam (1910), Ruch antywiwisekcyjny, Druk W.A. Anczyca i Spółki, Kraków.

Wundt Wilhelm (1873), Wykłady o duszy ludzkiej i zwierzęcej, przekład z niemieckiego, cz. 1, Nakładem A. Dygasińskiego i Małuji, Kraków 1873.

\section{| Abstrakt}

\section{TOMAsz SOBIERAJ}

Wyłom w antropocentryzmie i gatunkowizmie? Przemiany świadomości w kulturowej na przykładzie relacji: człowiek - zwierzęce gatunki nie-ludzkie w drugiej połowie XIX wieku

Artykuł zawiera interpretację wybranych polskich tekstów popularnonaukowych i kulturalnych opublikowanych w drugiej połowie XIX wieku. Wszystkie były poświęcone relacjom: człowiek - zwierzęta nie-ludzkie oraz statusowi tych drugich w społeczeństwie ludzkim. Teksty te ukazują przemiany, jakim ulegała europejska świadomość kulturowa. Polegały one na stopniowym odrzuceniu myślenia antropocentrycznego oraz szowinizmu gatunkowego. Wszyscy autorzy protestowali przeciwko zadawaniu cierpienia i prześladowaniom zwierząt. Pod wpływem Darwina i rozwoju dziewiętnastowiecznego przyrodoznawstwa dokonywał się przełom w spojrzeniu na kondycję człowieka oraz jego związek ze zwierzętami. Choć nie bez oporów i trudności, zwierzęta zaczęto traktować jako żywe, podatne na cierpienia 
istnienia, które mają bogate życie psychiczne. Wielu uczonych i intelektualistów zaczęło kwestionować tradycyjny pogląd na status zwierząt nie-ludzkich, zdominowany przez antropocentryczne stereotypy.

Słowa kluczowe: antropocentryzm, szowinizm gatunkowy, cierpienie zwierząt, natura

\section{| Abstract}

Tomasz Sobieraj

\section{A Breach in Anthropocentrism and Speciesism? Changes in Cultural Consciousness on the Example of the Relationship: Human - Non-human Animal Species in the Second Half of the Nineteenth Century}

The article contains an interpretation of selected Polish popular science and cultural texts published in the second half of the nineteenth century. All of them were devoted to the relationship: human - nonhuman animals and the status of the latter in human society. These texts - written by positivists and naturalists - show the changes which European cultural awareness has undergone. They consisted in a gradual abandonment of anthropocentric thinking and speciesism. All the authors protested against inflicting suffering and persecution of animals. Under the influence of Darwin and the development of 19th-century natural science, a breakthrough in the perception of the human condition and its relationship with animals took place. Although not without resistance and difficulties, animals began to be treated as living beings, susceptible to suffering, with a rich mental life. Many scientists and intellectuals began challenging the traditional view of the status of nonhuman animals dominated by anthropocentric stereotypes.

Keywords: anthropocentrism, speciesism, animal suffering, nature

\section{| Biogram}

Tomasz Sobieraj - prof. zw.; kierownik Zakładu Literatury Pozytywizmu i Młodej Polski w Instytucie Filologii Polskiej UAM. Historyk literatury i kultury drugiej połowy XIX wieku, badacz powieści, krytyki literackiej i teatralnej oraz związków literatury z przyrodoznawstwem, edytor naukowy. Ostatnie publikacje książkowe: Stanisław Brzozowski. Przybliżenia (2016), Między konwencja a innowacją. Szkice 
o polskim dramacie i teatrze drugiej połowy XIX i początku XX wieku (2018), Artysta, sztuka i społeczeństwo. Spory i polemiki wokót „Confiteor” Stanisława Przybyszewskiego (2019).

E-mail: lotario@amu.edu.pl, tomas.sob_xl@wp.pl

ORCID: oooo-0002-4563-5574 